\title{
Operational risks and building energy efficiency
}

\author{
Victoria Borkovskaya ${ }^{1}$, Evgeniy Degaev ${ }^{2 *}$, Vladimir Rimshin ${ }^{2}$ and Igor Shubin ${ }^{3}$ \\ ${ }^{1}$ Plekhanov Russian University of Economics, Stremyanny Lane, 36, 117997, Moscow, Russia \\ 2,Moscow State University of Civil Engineering, Yaroslavskoe shosse, 26, 129337, Moscow, Russia \\ ${ }^{3}$ Research Institute of Building Physics, Moscow, Russia
}

\begin{abstract}
The article discusses the main aspects of the Federal program of energy saving and energy efficiency of the housing and communal complex. The algorithm of energy survey of the building is given. The calculation of the temperature field of structural units using the ELCUT software package is considered. The operational risks of implementing the energy saving Program and improving the energy efficiency of the housing stock are determined.
\end{abstract}

\section{Introduction}

The formation of energy-efficient housing and communal services in Russia is an integral part of the development of the Russian economy. The transition to an energyefficient development option must be made in the coming years, otherwise economic growth will be constrained by high prices and reduced availability of energy resources.

The Federal law "on energy saving and energy efficiency improvement and on amendments to certain legislative acts of the Russian Federation" has defined a new stage in the development of legislation on energy saving and energy efficiency improvement in the Russian Federation. Significant changes in the system of state regulation measures in the field of energy saving and energy efficiency have led to the rapid development and adoption of a large number of bylaws. The division of powers of the state authorities of the Russian Federation and the subjects of the Russian Federation, as well as local selfgovernment bodies in the field of energy saving and energy efficiency was made, which allowed creating conditions for the development of the appropriate regulatory framework at all levels of state and municipal administration and determining the legal basis for their interaction.

The Russian Federation has one of the world's largest technical potentials for energy conservation and energy efficiency, which accounts for more than 40 percent of energy consumption. The assessment is given to the level of 2007, as the base for the Decree of the President of the Russian Federation of June 4, 2008 No. 889. In absolute volumes, this potential is 403 million tons of conventional fuel, and taking into account the reduction of associated gas flaring-420 million tons of conventional fuel. This is higher than the increase in primary energy production in Russia in 2008-2020 by 244-270 million tons of conventional fuel, as stipulated in the Russian Energy strategy for the period up to 2030,

\footnotetext{
*Corresponding author: Borkovskaya.VG@,rea.ru, degaev@inbox.ru
} 
approved by the order of the Government of the Russian Federation dated November 13, 2009 N 1715 - p.

In the Russian Federation for the end of 2018, there were 1110977 apartment buildings. Among them, 598,730 MCD (54\%) with a reduced energy efficiency class (E, F, $\mathrm{G})$, as well as an undefined energy efficiency class. In 2018, 3,636 multi-apartment buildings with a preliminary energy efficiency class of at least $\mathrm{C} 1$ were put into operation, which was $27 \%$ of the total number of MCD units introduced in the country (13,457 units) (table 1). The majority of MCD's that are put into operation are houses with high energy consumption. $\mathrm{C}$ the amount of utility payments in such homes is less than in homes with lower and lower energy efficiency classes. The cost of building an energy-efficient MCD with energy efficiency class $(\mathrm{A}++, \mathrm{A}+, \mathrm{A}, \mathrm{B}, \mathrm{C})$ is $10-25 \%$ higher than the cost of $\mathrm{MCD}$ with normal (D) and reduced (E, F, G) energy efficiency classes. At the same time, the utility fee in an energy-efficient MCD is lower by 30 to $60 \%$ than in an MCD with a normal or reduced energy efficiency class. Thus, the additional cost of an energy-efficient MCD is paid for by saving on utility bills [1-3].

Table 1. Information on the distribution of the introduced MCD by energy efficiency classes in 2018.

\begin{tabular}{|c|c|}
\hline Energy efficiency class MCD & The amount of MCD \\
\hline A & 823 \\
\hline B & 1847 \\
\hline C & 966 \\
\hline D & 9748 \\
\hline F & 85 \\
\hline G & 14 \\
\hline
\end{tabular}

Technical measures for energy saving and improving energy efficiency in the housing stock, according to the Program, are shown in table 2

Table 2. Technical measures for energy saving and improving energy efficiency in the housing stock.

\begin{tabular}{|c|c|c|c|c|c|c|c|c|c|c|c|}
\hline \multirow[t]{2}{*}{ Events } & \multirow[t]{2}{*}{ Unit } & \multicolumn{10}{|c|}{ Years } \\
\hline & & 2011 & 2012 & 2013 & 2014 & 2015 & 2016 & 2017 & 2018 & 2019 & 2020 \\
\hline $\begin{array}{l}\text { The installation of the } \\
\text { collective } \\
\text { (obschedomovyh) } \\
\text { metering devices of } \\
\text { thermal energy }\end{array}$ & $\begin{array}{l}\text { thousand } \\
\text { pieces }\end{array}$ & $\frac{\hat{n}}{n}$ & 守 & $\underset{i}{i}$ & $\underset{\dot{\infty}}{i n}$ & $\stackrel{+}{n}$ & ' & ' & ' & ' & ' \\
\hline $\begin{array}{l}\text { Comprehensive energy- } \\
\text { saving overhaul of multi- } \\
\text { apartment residential } \\
\text { buildings }\end{array}$ & $\begin{array}{l}\text { thousand sq. } \\
\text { m. }\end{array}$ & ' & ' & \begin{tabular}{l}
8 \\
8 \\
\hdashline
\end{tabular} & ষ্ঠ & 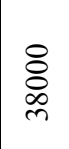 & 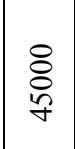 & $\frac{8}{8}$ & $\begin{array}{l}8 \\
8 \\
\text { D } \\
\text { n }\end{array}$ & $\begin{array}{l}8 \\
8 \\
0 \\
\text { in }\end{array}$ & 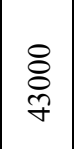 \\
\hline $\begin{array}{l}\text { Percentage of multi-family } \\
\text { residential buildings where } \\
\text { energy surveys were } \\
\text { conducted (for the previous } \\
5 \text { years) }\end{array}$ & $\%$ & ิ & $\stackrel{m}{\text { m }}$ & \& & 으 & in & 으 & 으 & 으 & 요 & in \\
\hline $\begin{array}{l}\text { Average specific heat } \\
\text { consumption for heating } \\
\text { purposes in residential } \\
\text { buildings }\end{array}$ & $\begin{array}{c}\mathrm{Gcal} / \mathrm{sq} \\
\mathrm{m} / \text { degree } \\
\text { day }\end{array}$ & 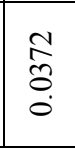 & 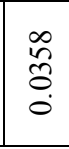 & $\begin{array}{l}\stackrel{n}{\mathscr{n}} \\
\stackrel{0}{0} \\
\stackrel{0}{0}\end{array}$ & $\begin{array}{l}\overrightarrow{\text { ⿵人 }} \\
\text { ô } \\
\stackrel{0}{0}\end{array}$ & $\begin{array}{l}\text { तै } \\
\text { ఠิ } \\
\stackrel{0}{0}\end{array}$ & $\begin{array}{l}\stackrel{\nabla}{0} \\
\stackrel{0}{0} \\
\stackrel{0}{0}\end{array}$ & 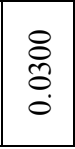 & $\begin{array}{l}\stackrel{2}{\hat{\jmath}} \\
\stackrel{0}{0}\end{array}$ & $\begin{array}{l}\overparen{\partial} \\
\text { ठ઼. } \\
\text {. }\end{array}$ & $\begin{array}{l}\infty \\
\infty \\
\stackrel{0}{0} \\
\stackrel{0}{0}\end{array}$ \\
\hline
\end{tabular}

\section{Materials and Methods}


The assessment of the state of energy saving and energy efficiency improvement is performed on the basis of indicators that characterize the results of the state policy in the field of energy saving and energy efficiency improvement carried out by the subjects of the Russian Federation. These indicators are:

* information about investments attracted for the implementation of energy saving and energy efficiency measures:

* the amount of extra-budgetary financing of the subjects of the Russian Federation for activities aimed at energy saving and improving energy efficiency;

- the volume of investments under energy service contracts aimed at energy saving and improving energy efficiency, and their number.

* technological indicators that characterize the consumption of energy resources, as well as indicators that characterize the level of implementation of technologies that have high energy efficiency:

* the share of multi-family residential buildings (MCD) with a preliminary energy efficiency class is not lower than $\mathrm{C}$;

* percentage of introduced MCD with individual heat points (ITP) with automatic weather control of the coolant temperature;

* percentage of availability of ITP with automatic weather control in buildings operated by public sector organizations;

* the percentage of MCD in which an ITP with automatic weather control of the coolant temperature was installed after major repairs;

* share of led light sources in the street and road sector;

* percentage of DSL equipment with metering devices of energy resources;

* specific expenditure of energy resources in the housing and utilities sector.

An important organizational measure for energy saving and improving energy efficiency in the housing stock is to conduct voluntary and mandatory energy surveys of housing stock objects [3-6]. 1.

In General, the energy survey is performed according to the algorithm shown in Figure

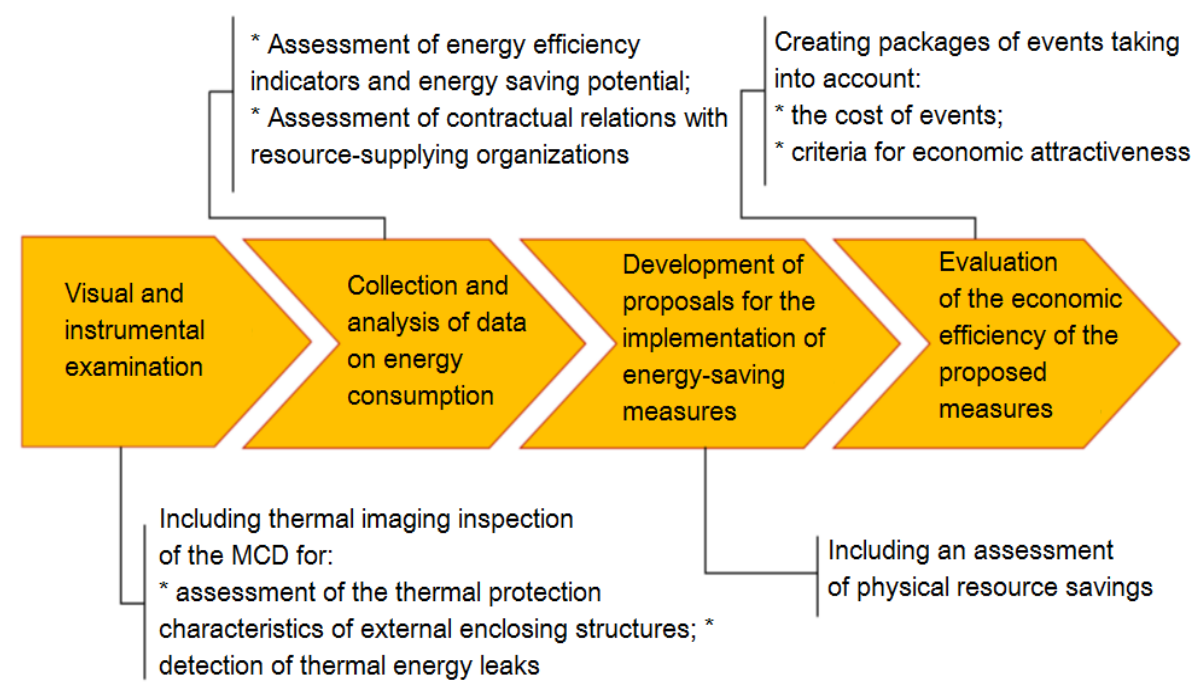

Fig. 1. The work carried out during the energy inspection of apartment houses management.

Practical calculations show that the greatest energy losses during the operation of MCD occur during heating and hot water supply, which is about $80 \%$ of all losses (figure 2). 


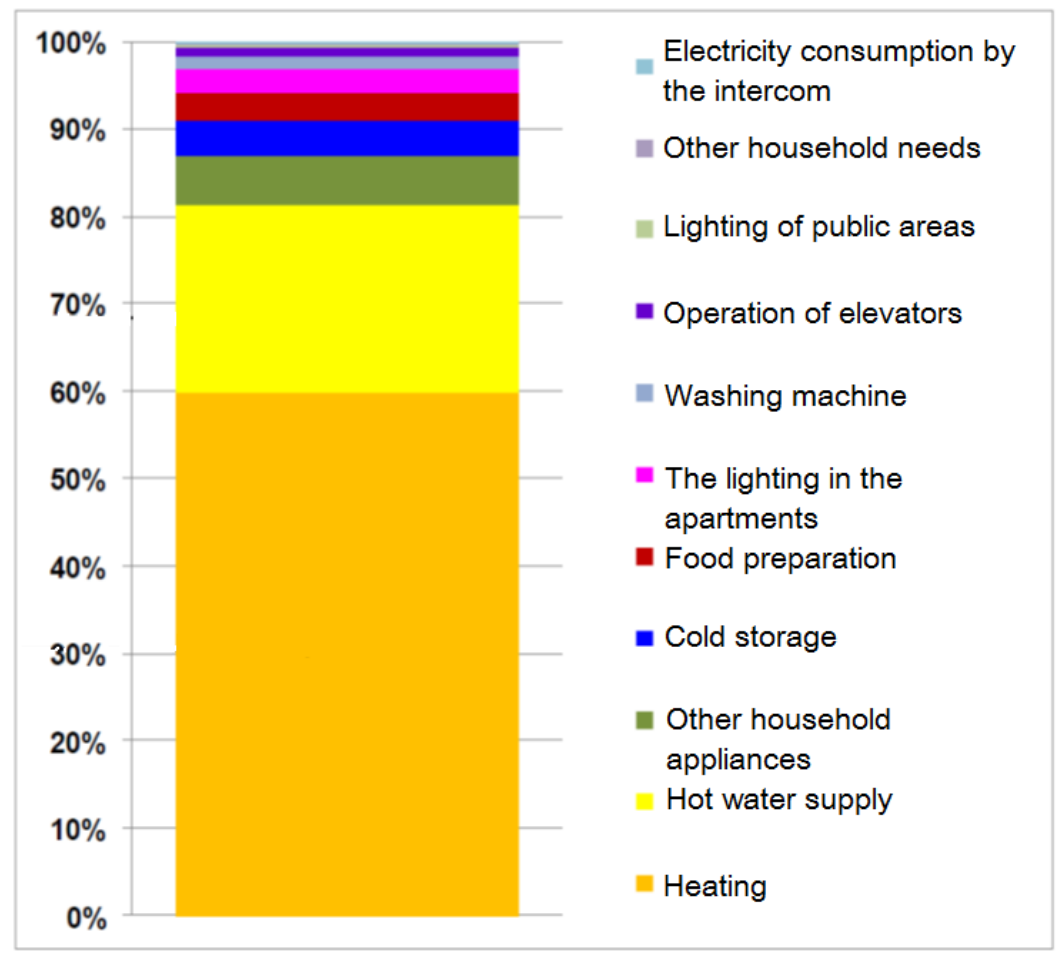

Fig. 2. Structure of energy consumption in an apartment building.

When designing major repairs of facades to achieve the required level of energy efficiency, it is necessary to calculate the thermal fields of structures and components [5-8].

\section{Results and Discussion}

The result of calculating the temperature field of the construction node is the distribution of temperatures in the node section, including on the inner and outer surfaces [9-13].

The heat flow through the inner surface of the node is determined by the formula:

$$
Q_{b}=\alpha_{b} S_{b}\left(t_{b}-\tau_{b}^{c p}\right) .
$$

The heat flow through the outer surface of the node is determined by the formula:

$$
Q_{b}=\alpha_{n} S_{n}\left(t_{n}-\tau_{n}^{c p}\right)
$$

$t_{b}, t_{n}-$ calculated indoor and outdoor air temperatures, respectively, ${ }^{\circ} \mathrm{C}$;

$\tau_{b}^{c p}, \tau_{n}^{c p}$ - area-averaged temperatures of the inner and outer surfaces of the enclosing structure node, respectively, ${ }^{\circ} \mathrm{C}$;

$\alpha_{b}, \alpha_{n}$ - heat transfer coefficients of the internal and external surfaces of the construction node, respectively, $\mathrm{W} /\left(\mathrm{m}^{\circ} \mathrm{C}\right)$;

$S_{b}, S_{n}$ - he area of the inner and outer surfaces of the node of the enclosing structure, $\mathrm{m}^{2}$.

Figures 3-5 show an example of calculating the temperature field of the facade structural elements produced in the ELCUT program. 


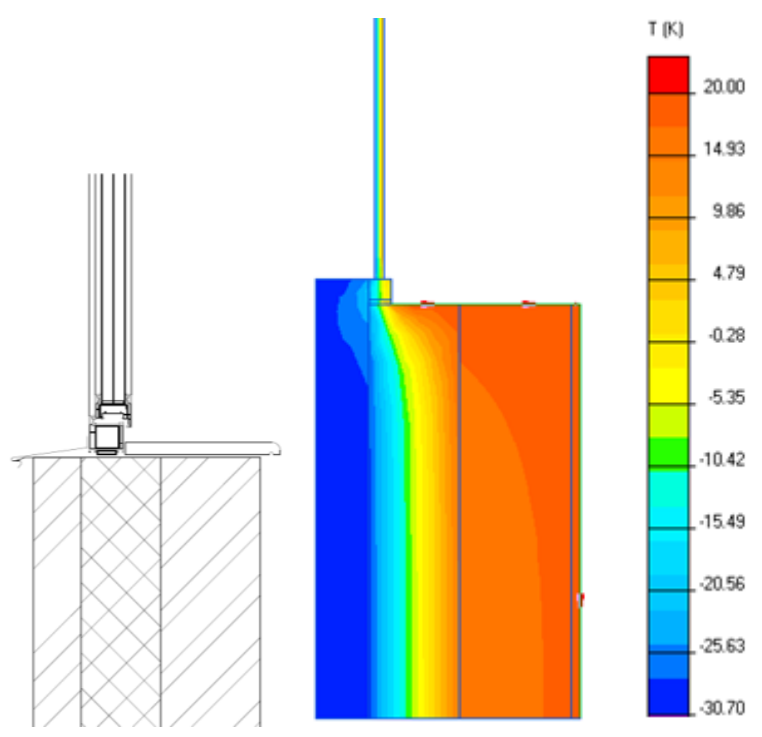

Fig. 3. Temperature distribution in the window-wall element.

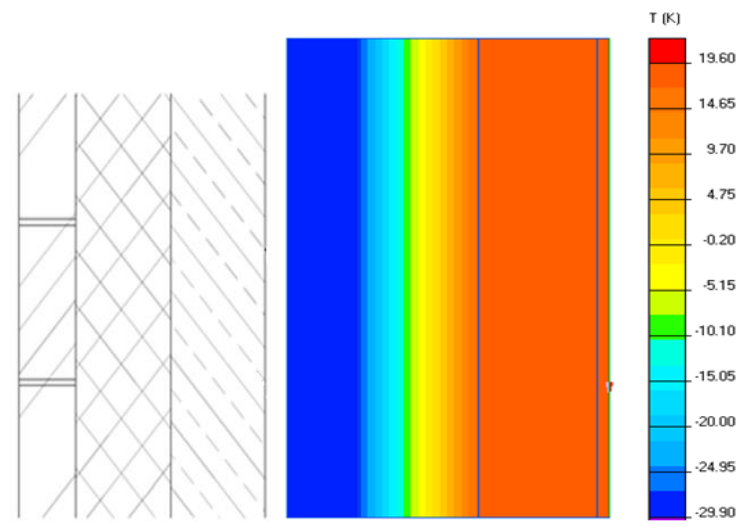

Fig. 4. Temperature distribution in the element of the enclosing structure (brick, insulation, reinforced concrete, plaster).

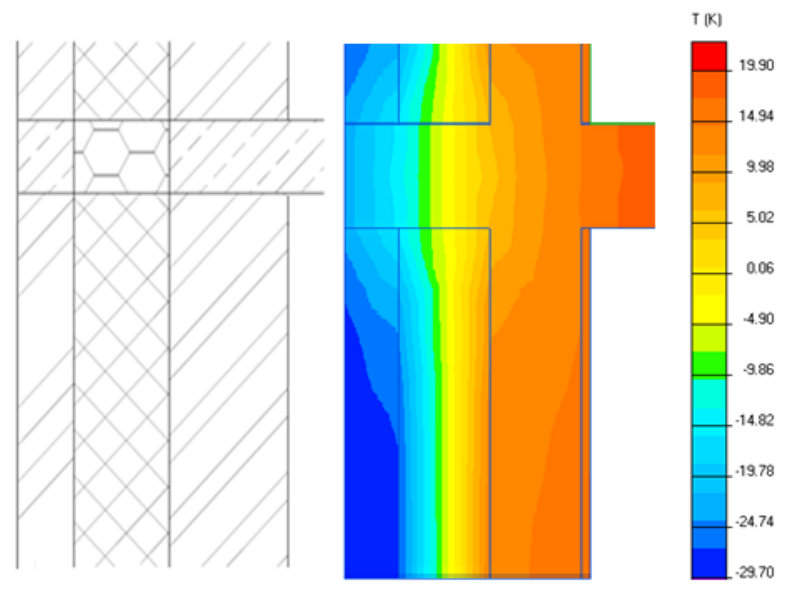

Fig. 5. Temperature distribution in the slab. 
The characteristics of the layers of the enclosing structure are shown in table 3.

Table 3. Characteristics of the layers of the enclosing structure.

\begin{tabular}{|l|c|c|}
\hline \multicolumn{1}{|c|}{ Material } & The thickness of the layer, $\mathbf{~ m ~}$ & $\begin{array}{c}\text { Thermal conductivity } \\
\text { coefficient, } \mathbf{~} /\left(\mathbf{m}^{\mathbf{0}} \mathbf{C}\right)\end{array}$ \\
\hline Solid brick & 0.12 & 0.67 \\
\hline Ferroconcrete & 0.2 & 1.7 \\
\hline Light mineral wool & 0.2 & 0.045 \\
\hline Dry plaster & 0.02 & 0.21 \\
\hline
\end{tabular}

Based on the software package, you can predict specific heat losses and choose the best way to insulate the façade [10].

\section{Conclusions}

Like any process, the Federal energy saving Program is not without risks. The main risks of implementing the energy saving Program in the housing stock are:

- a processing error;

- lack of supervision, reliability, and control;

- insufficient financing;

- the incompetence of the contractors.

In this case, it is recommended to conduct the risk management process at two subordinate levels - Executive and coordinating. At the execution level, continuous monitoring and management of risk levels is provided - preparation and implementation of solutions to prevent or correct adverse risk events. Negative trends are identified and the consequences of irrational decisions are eliminated (the function "monitoring the level of operational risks"), and risks are analyzed during the preparation of strategic, tactical or operational decisions (the function "managing the level of risk in the preparation of decisions") [9-11].

\section{References}

1. V.G. Borkovskaya, E.N. Degaev, I. Burkova, MATEC Web of Conferences 193, 05027 (2018) DOI: https://doi.org/10.1051/matecconf/201819305027

2. V. Polyakova, E.N. Degaev, P. El Haddad, MATEC Web of Conferences 251, 06017 (2018) DOI: https://doi.org/10.1051/matecconf/201825106017

3. E.N. Degaev, MATEC Web of Conferences 193, 02032 (2018) DOI: https://doi.org/10.1051/matecconf/201819302032

4. E.N. Degaev, A. Orlov, P. El Haddad, A. Pleshivtsev, MATEC Web of Conferences 251, 06013 (2018) DOI: https://doi.org/10.1051/matecconf/201825106013

5. E.N. Degaev, A. Suvorova A. Suhova, IOP Conf. Ser.: Mater. Sci. Eng. 365, 032019 (2018) DOI: https://doi.org/10.1088/1757-899X/365/3/032019

6. E. Degaev, V. Rimshin, J. Phys. Conf. Ser. 1425, 012153 (2019) DOI: https://doi.org/10.1088/1742-6596/1425/1/012153

7. E. Degaev, R. Barkhi, J. Phys. Conf. Ser. 1425, 012066 (2019) DOI: https://doi.org/10.1088/1742-6596/1425/1/012066

8. V.G. Borkovskaya, Materials Science and Mechanical Engineering. 2, 287-290 (2013). DOI: 10.4028/www.scientific.net/AMM.467.287 
9. V.G. Borkovskaya Advanced Materials Research 860-863, 3009-3012 (2013). DOI: 10.4028/www.scientific.net/AMR.860-863.3009

10. V.G. Borkovskaya Applied Mechanics and Materials 475-476, 1703-1706 (2013). DOI: 10.4028/www.scientific.net/AMM.475-476.1703

11. V. Borkovskaya, D. Passmore, MATEC Web of Conf. 193, 05027 (2018). DOI: https://doi.org/10.1051/matecconf/201819305026

12. V.G, Borkovskaya, D. Passmore, Smart Technologies and Innovations in Design for Control of Technological Processes and Objects: Economy and Production 24 (2018), DOI:10.1007/978-3-030-15577-3_24

13. V.G. Borkovskaya, MATEC Web of Conferences 251, 06025 (2018). DOI: https://doi.org/10.1051/matecconf/201825106025

14. V. Rimshin, B. Labudin, V. Morozov, A. Kazarian, V. Kazaryan, EMMFT-2019, 983, 867-876 (2019)

15. E. Kuzina. V. Rimshin, Advances in Intelligent Systems and Computing 983, 911-919 (2019)

16. A. Varlamov, V. Rimshin, S. Tverskoi, E3S Web of Conferences 91, 02046 (2019)

17. V.O. Evseev, V.G. Borkovskaya, R. Barkhi, IOP Conf. Series: Journal of Physics: Conf. Series 1425, 012175 (2020). doi:10.1088/1742-6596/1425/1/012175

18. D. Passmore, V.G. Borkovskaya, IOP Conf. Series: Journal of Physics: Conf. Series 1425, 012166 (2020). doi:10.1088/1742-6596/1425/1/012166

19. E. Kuzina, V. Rimshin, V. Kurbatov, IOP Conference Series: Materials Science and Engineering 463(4), 042009 (2018)

20. A.A. Varlamov, V.I. Rimshin, S.Y. Tverskoi, IOP Conference Series: Materials Science and Engineering 463(2), 022028 (2018)

21. A.A. Varlamov, V.I. Rimshin, S.Y. Tverskoi, IOP Conference Series: Materials Science and Engineering 463(2), 022029 (2018)

22. N.I. Karpenko, V.A. Eryshev, V.I. Rimshin, IOP Conference Series: Materials Science and Engineering 463(3), 032024 (2018)

23. E. Kuzina, V. Rimshin, Advances in Intelligent Systems and Computing 692, 410-416 (2018)

24. E. Kuzina, A. Cherkas, V. Rimshin, IOP Conference Series: Materials Science and Engineering 365(3), 032053 (2018)

25. V.G. Borkovskaya, Yu. Korytova, IOP Conference Series: Materials Science and Engineering 661(1) (2019)

26. A.A. Varlamov, V.I. Rimshin, S.Y. Tverskoi, IFAC-PapersOnLine 51(30), 808$811(2018)$ 